\title{
PENDIDIKAN KESEHATAN TENTANG PENYAKIT MENULAR
}

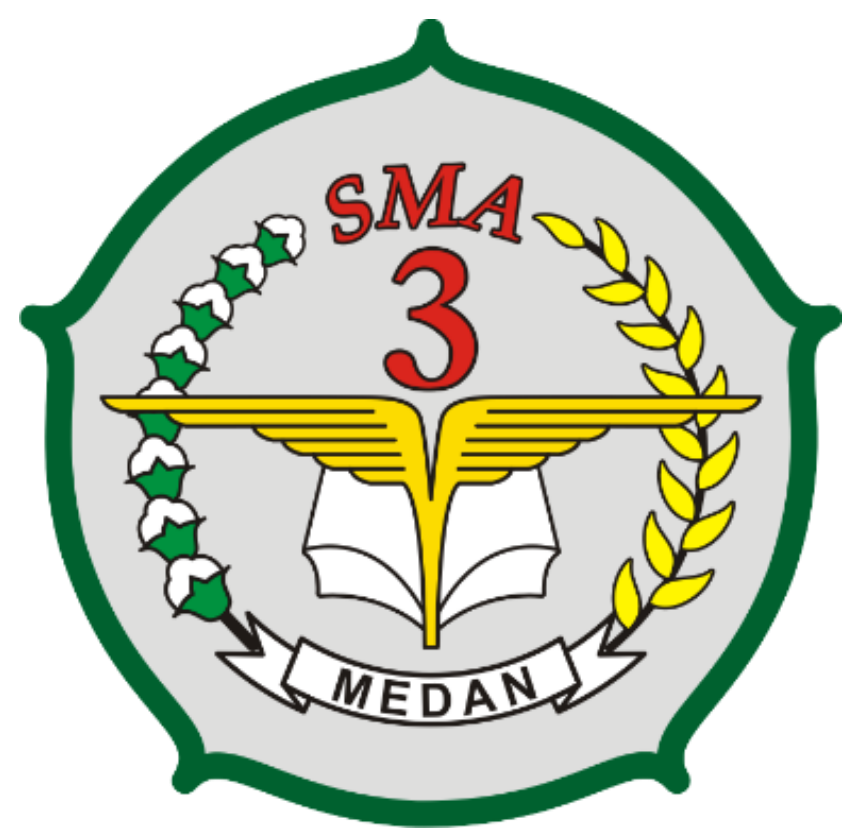

\section{DISUSUN OLEH :}

FANNISA ADANI SUHARTONO

X MIA 3

T.A 2019/2020

SMA NEGERI 3 MEDAN 


\section{KATA PENGANTAR}

Puji syukur penulis ucapkan kepada Allah SWT, yang telah memberikan rahmat dan karuniaNya sehingga makalah yang berjudul "Pendidikan Kesehatan tentang Penyakit Menular" ini dapat diselesaikan dengan baik. Tidak lupa shalawat dan salam semoga terlimpahkan kepada Rasulullah Muhammad SAW, keluarganya, sahabatnya, dan kepada kita selaku umatnya.

Makalah ini penulis buat untuk melengkapi tugas mata pelajaran PJOK. Saya ucapkan terima kasih kepada semua pihak yang telah membantu dalam penyusunan makalah ini. Dan Saya juga menyadari pentingnya akan sumber bacaan dan referensi internet yang telah membantu dalam memberikan informasi yang akan menjadi bahan makalah.

Saya juga mengucapkan terima kasih kepada semua pihak yang telah memberikan arahan serta bimbingannya selama ini sehingga penyusunan makalah dapat dibuat dengan sebaik-baiknya. Saya menyadari masih banyak kekurangan dalam penulisan makalah ini sehingga Saya mengharapkan kritik dan saran yang bersifat membangun demi penyempurnaan makalah ini.

Saya mohon maaf jika di dalam makalah ini terdapat banyak kesalahan dan kekurangan, karena kesempurnaan hanya milik Yang Maha Kuasa yaitu Allah SWT, dan kekurangan pasti milik kita sebagai manusia. Semoga makalah ini dapat bermanfaat bagi kita semuanya.

Medan, 4 Mei 2020

Fannisa Adani Suhartono 


\section{DAFTAR ISI}

COVER. .. $\mathrm{i}$

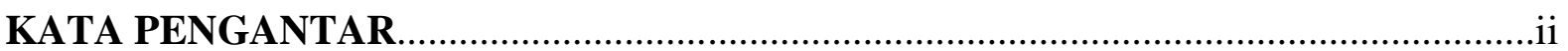

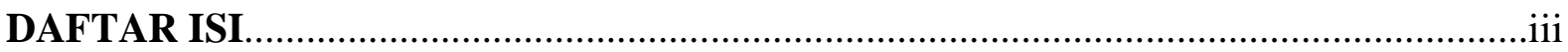

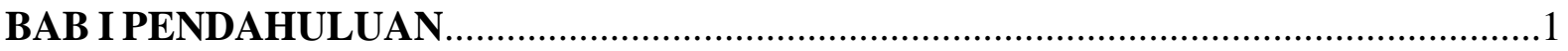

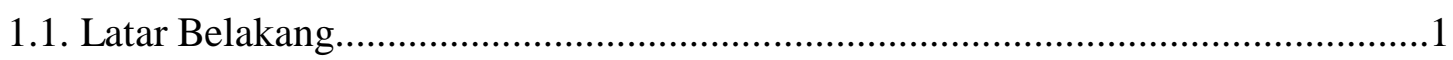

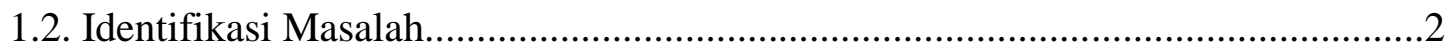

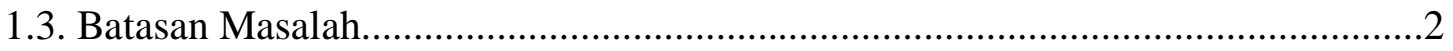

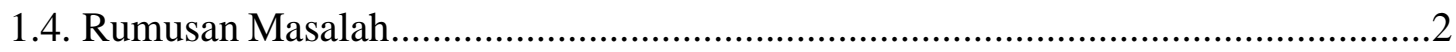

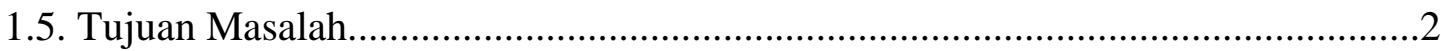

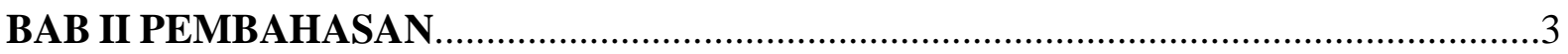

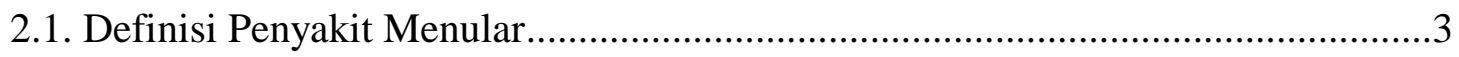

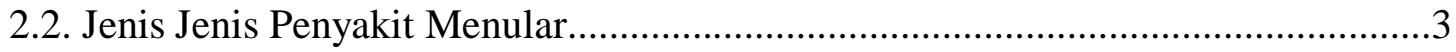

2.2.1.Diare

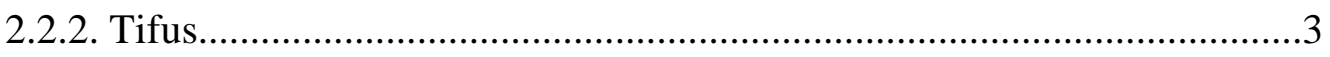

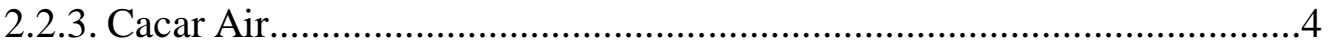

2.2.4. Penyakit Seks Menular (PMS) ..........................................................

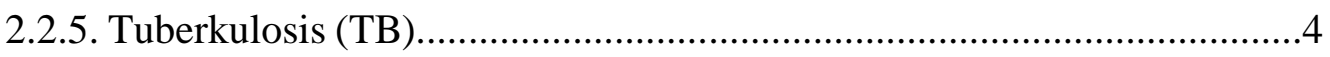

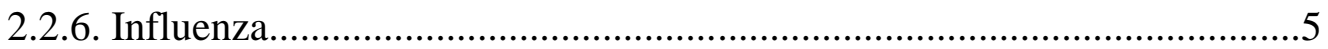

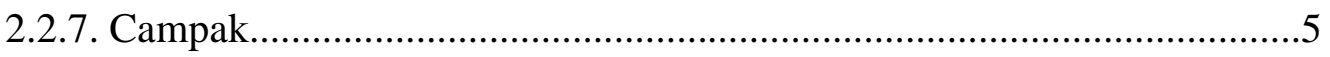

2.2.8. Pneumonia....................................................................................... 6

2.2.9. Acquired Immunodeficiency Syndrome (AIDS)..................................6

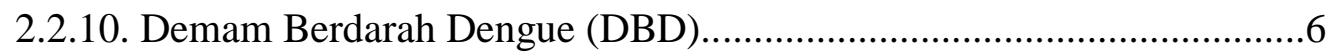

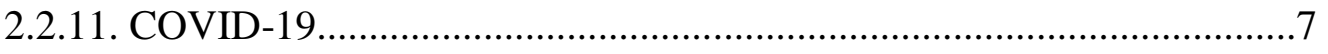


2.3. Munculnya COVID-19.

2.4. Penyebaran COVID-19 ke Penjuru Dunia ........................................................

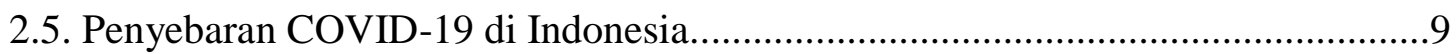

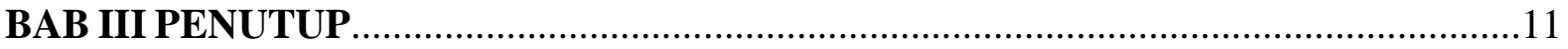

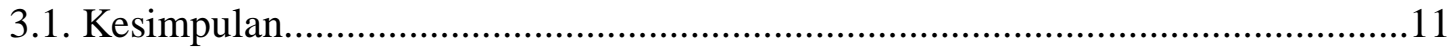

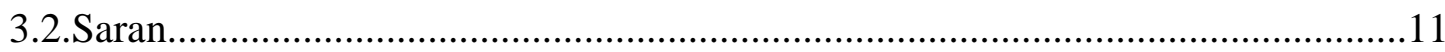

DAFTAR PUSTAKA 


\section{BAB I}

\section{PENDAHULUAN}

\subsection{LATAR BELAKANG}

Di dunia ini, manusia bisa mengidap macam-macam penyakit yang menyerang tubuh. Macam-macam penyakit yang terjadi pada manusia juga berasal dari faktor yang berbeda. Manusia dapat terserang penyakit karena tertular, atau akibat bakteri hingga virus, bahkan karena faktor keturunan.

Penyakit menular menurut para ahli adalah sebuah penyakit yang dapat berpindah dari satu orang ke orang lain. Hal tersebut disebut dengan penularan yang bisa terjadi secara langsung atau tidak langsung dan juga bisa menular melalui perantara atau penghubung. Penyakit menular biasanya ditandai dengan adanya penyebab penyakit yang hidup dan bisa

berpindah menyerang inang (penderita). Penyakit menular bisa berpindah pindah dari satu orang ke orang lain. Proses penularan inilah yang harus kita cegah. Untuk bisa mencegah penularannya tentu kita harus mengetahui apa saja media yang bisa menjadi perantara cikal bakal penyakit itu. Jika sudah tahu, barulah kita menghindarinya.

Dan di antara penyakit menular tersebut termasuk jugalah penyakit yang sangat dikenali oleh orang saat ini yaitu COVID-19 atau Corona Virus Disease 2019 yang disebabkan oleh kelompok virus coronavirus. Coronavirus adalah kumpulan virus yang bisa menginfeksi sistem pernapasan. Pada banyak kasus, virus ini hanya menyebabkan infeksi pernapasan ringan, seperti flu. Namun, virus ini juga bisa menyebabkan infeksi pernapasan berat, seperti infeksi paru-paru (pneumonia).

Infeksi virus COVID-19 pertama kali ditemukan di kota Wuhan, China pada akhir Desember 2019. Virus ini menular dengan sangat cepat dan telah menyebar ke hampir semua negara, termasuk Indonesia, hanya dalam waktu beberapa bulan.

Pandemi ini juga menyebabkan gangguan sosioekonomi global,penundaan atau pembatalan acara olahraga dan budaya,dan kekhawatiran luas tentang kekurangan persediaan barang yang mendorong pembelian panik, dan tidak hanya itu. Misinformasi dan teori konspirasi tentang virus-pun telah menyebar secara daring, dan terjadinya insiden xenophobia dan rasisme terhadap orang Tiongkok dan orang-orang Asia Timur dan Tenggara. 


\subsection{IDENTIFIKASI MASALAH}

Berdasarkan latar belakang di atas masalah yang dapat diidentifikasi adalah, masih banyaknya orang yang belum memahami betul mengenai penyakit menular dimana masih ada orang yang kurang memahami tentang penyebaran penyakit menyebar ini dan pandemi COVID-19 terutama dengan adanya misinformasi lewat daring, xenophobia, ataupun rasisme dan lain lainnya.

\subsection{BATASAN MASALAH}

Dalam makalah ini, penulis hanya akan membahas mengenai pengertian, jenis jenis penyakit menular yang sering diderita oleh orang Indonesia, asal usul COVID-19, proses penyebaran COVID-19 di penjuru dunia, dan di Indonesia.

\subsection{RUMUSAN MASALAH}

1) Apa itu Penyakit Menular?

2) Apa saja Jenis jenis dari Penyakit Menular?

3) Bagaimana asal usul munculnya penyakit virus COVID-19?

4) Bagaimana proses menyebarnya COVID-19 ke penjuru dunia?

5) Bagaimana proses menyebarnya COVID-19 di Indonesia?

\subsection{TUJUAN MASALAH}

Tujuan disusunnya Makalah ini yaitu untuk,

1) Untuk mengetahui pengertian dari Penyakit Menular

2) Untuk mengetahui jenis jenis dari Penyakit Menular

3) Untuk mengetahui asal usul munculnya penyakit virus COVID-19

4) Untuk mengetahui proses menyebarnya COVID-19 ke penjuru dunia

5) Untuk mengetahui proses menyebarnya COVID-19 di Indonesia 


\section{BAB II}

\section{PEMBAHASAN}

\subsection{DEFINISI PENYAKIT MENULAR}

Penyakit menular menurut para ahli adalah sebuah penyakit yang dapat berpindah dari satu orang ke orang lain. Hal tersebut disebut dengan penularan yang bisa terjadi secara langsung atau tidak langsung dan juga bisa menular melalui perantara atau penghubung. Penyakit menular biasanya ditandai dengan adanya penyebab penyakit yang hidup dan bisa berpindah menyerang inang (penderita).

Penyakit menular bisa berpindah pindah dari satu orang ke orang lain. Proses penularan inilah yang harus kita cegah. Untuk bisa mencegah penularannya tenti kita harus mengetahui apa saja media yang bisa menjadi perantara cikal bakal penyakit itu.

\subsection{JENIS JENIS PENYAKIT MENULAR}

\subsubsection{Diare}

Diare adalah penyakit menular yang disebabkan oleh virus. Orang yang terkena diare akan mengalami gangguan buang air besar (BAB). Penyakit ini ditandai dengan $\mathrm{BAB}$ lebih dari tiga kali dalam sehari, dengan konsistensi tinja dalam bentuk yang cair. Diare juga dapat disertai dengan keluarnya darah atau lendir saat $\mathrm{BAB}$.

Diare menular melalui tanah, air, atau makanan yang terkontaminasi virus, bakteri atau parasit. Penularan diare dapat dihindari dengan selalu menjaga kebersihan seperti mencuci dengan sabun antiseptik sebelum makan, sesudah buang air besar atau kecil, dan setelah keluar dari kamar mandi. Mengonsumsi makanan yang sudah dimasak dengan matang juga akan menurunkan risiko seseorang terkena diare.

\subsubsection{Tifus}

Tifus adalah penyakit infeksi berkelompok yang meliputi berbagai jenis demam yang disebabkan oleh infeksi bakteri Salmonella typhi. Bakteri ini bisa dibawa oleh ektoparasit seperti kutu dan tungau yang kemudian menginfeksi 
manusia. Bakteri ini biasanya sering ditemukan pada hewan seperti tikus, kucing, dan tupai. Bakteri ini juga dapat terbawa melalui pakaian, seprai, kulit, dan rambut.

Untuk mencegah tifus bisa dilakukan dengan menghindari kontak langsung dengan penderita dalam jangka waktu yang lama. Selain itu, hindari juga kebiasaan menggunakan barang-barang pribadi secara bersama-sama. Jika diperlukan, konsumsi antibiotik yang diresepkan oleh dokter dan ikuti petunjuk pemakaiannya.

\subsubsection{Cacar Air}

Cacar air adalah penyakit yang dapat menular dengan cepat dan mudah. Namun pada umumnya cacar air hanya akan menyerang pada anak-anak. Tapi tidak menutup kemungkinan orang dewasa juga akan mengalami hal ini. Gejala yang paling umum dari penyakit cacar air ini adalah demam, tubuh terasa lelah, hilangnya selera makan dan ruam yang gatal seperti melepuh pada kulit.

Cacar air dapat dicegah dengan melakukan vaksinasi. Pemberian vaksin ini dilakukan agar orang terhindari dari risiko tertular virus cacar air atau menularkan cacar air kepada orang lain. Pencegahan lain yang juga perlu dilakukan adalah mengisolasi penderita cacar air dari tempat-tempat umum agar tidak menyebarkan kepada orang lain.

\subsubsection{Penyakit Menular Seksual (PMS)}

Penyakit menular seksual atau PMS dikenal juga sebagai infeksi menular seksual atau IMS. Penyakit ini cukup berbahaya dan dapat ditularkan hanya jika seseorang melakukan hubungan seksual yang berisiko, atau hubungan seksual yang tidak aman. Penyakit ini dapat menular melalui sperma, cairan vagina, darah, ataupun cairan tubuh lainnya. Ada beberapa penyakit menular seksual lainnya seperti sifilis, gonore, herpes, dan masih banyak lainnya.

Penyakit menular seksual dapat dicegah dengan tidak berganti-ganti pasangan. Dan juga menggunakan alat pengaman, alat kontrasepsi ataupun kondom setiap berhubungan seksual dengan pasangan.

\subsubsection{Tuberkulosis (TB)}

Tuberkulosis (TB) adalah penyakit menular yang juga paling merenggut nyawa. Tuberkulosis disebabkan oleh bakteri yang menyerang paru-paru. Namun tuberkulosis juga dapat menyerang tulang, sendi, selaput otak atau yang biasa 
disebut meningitis TB, kelenjar getah bening atau TB kelenjar, dan selaput jantung. Bakteri ini sangat mudah tertularkan melalui udara saat penderita batuk atau bersin.

Untuk menghindari penularan TB, dapat dilakukan dengan menggunakan masker saat berada di keramaian, terutama saat berinteraksi dengan pengidap TB. Sirkulasi udara yang cukup di dalam rumah juga menjadi faktor yang dapat mencegah penyakit TB. TB juga dapat dicegah dengan pemberian vaksin BCG.

\subsubsection{Influenza}

Influenza atau yang lebih umum dikenal dengan flu adalah penyakit menular yang paling umum diderita oleh orang-orang. Influenza ini disebabkan oleh virus. Virus influenza adalah virus yang setiap waktunya bermutasi, sehingga sistem imunitas tubuh sulit mendeteksi virus yang satu ini. Karena sulitnya sistem imun tubuh mendeteksi virus influenza ini, maka tubuh cenderung lebih mudah terkena flu. Bahkan tubuh dapat beberapa kali terkena flu dalam waktu yang berdekatan.

Flu dapat ditularkan melalui sistem pernapasan juga melalui air ludah. Maka jika kita berdekatan dengan orang yang sedang flu, kemungkinan kita tertular flu sangatlah besar. Perantara udara adalah media penularan flu yang paling cepat.

Menjaga daya tahan tubuh agar tidak mudah terserang virus. Misalnya dengan makan teratur, istirahat yang cukup, minum air putih sesuai kebutuhan, berolah raga, dan memiliki gaya hidup yang sehat. Selain itu, menjaga daya tahan tubuh juga dapat juga didukung dengan asupan vitamin terutama Vitamin $\mathrm{C}$ yang bisa didapatkan di buah-buahan maupun vitamin yang dijual di toko-toko. Pencegahan lainnya adalah dengan menggunakan masker di tempat umum, terutama bagi yang menderita influenza.

\subsubsection{Campak}

Campak adalah penyakit menular yang disebabkan oleh virus yang termasuk ke dalam golongan paramixovirus. Campak sangat menular. Biasanya gejalanya berupa naiknya suhu tubuh, batuk, nyeri tenggorokan, nyeri otot, hingga ruam pada kulit. Gejala ini muncul sekitar 7-14 hari setelah terinfeksi virus.

Campak menular melalui cairan ludah dari penderita ketika batuk ataupun bersin. Campak dapat dihindari dengan melakukan vaksinasi yang biasa dilaksanakan ketika masih usia balita. 


\subsubsection{Pneumonia}

Pneumonia atau radang paru-paru adalah suatu peradangan yang disebabkan oleh bakteri, virus, maupun parasit lainnya. Peradangan terjadi pada pulmonary alveolus (alveoli) yang seharusnya bertugas untuk menyerap oksigen dari atmosfer. Akan tetapi karena terjadinya peradangan, organ ini menjadi terisi cairan sehingga penyerapan oksigen terganggu dan menyebabkan sulit bernapas. Gejalanya dimulai dari demam, batuk, hingga mengalami kesulitan bernapas.

Pneumonia dapat menyebar melalui udara yang tercemar oleh bakteri, virus, atau parasit penyebab pneumonia. Begitu juga udara yang terpapar penyebab pneumonia yang berasal dari penderita. Pencegahan juga dapat dilakukan dengan mengenakan masker atau pelindung pernapasan apabila dekat dengan sumber risiko penularan pneumonia, dan tidak lupa untuk menjaga daya tahan tubuh agar tetap kuat melawan semua virus atau bakteri yang masuk ke dalam tubuh.

\subsubsection{Acquired Immunodeficiency Syndrome (AIDS)}

AIDS adalah penyakit yang menyerang pada sel-sel darah putih yang bertugas untuk membentuk kekebalan tubuh. Akibatnya, daya tahan tubuh menjadi merosot dan sangat mudah dihinggapi berbagai macam penyakit. AIDS dapat menyebabkan kematian.

AIDS dapat tersebar melalui hubugan seksual dengan penderita yang terkena AIDS, melalui cairan tubuh penderita AIDS, AIDS juga dapat ditularkan oleh ibu yang tengah mengandung pada bayi yang dikandungnya.

Hal yang bisa kita lakukan untuk terhindar dari AIDS adalah dengan menghindari kontak dengan cairan tubuh penderita AIDS, seperti sperma, air liur, air seni, darah, dan cairan tubuh penderita lainnya. Bagi wanita yang tengah mengandung, jauhkanlah diri dari penderita AIDS, karena akan sangat berbahaya bagi dirinya dan bayi yang dikandungnya, dan pemisahan benda-benda pribadi dengan penderita AIDS.

\subsubsection{Demam Berdarah Dengue (DBD)}

DBD adalah penyakit menular yang disebabkan oleh virus dengue yang dibawa oleh nyamuk Aedes aegeypti Betina. Gejala yang umum terjadi adalah 
demam tinggi pada beberapa hari, sakit pada persendian, munculnya bintik-bintik merah, turunnya trombosit secara drastis, dan bisa terjadi pendarahan.

DBD dapat ditularkan melalui gigitan nyamuk betina Aedes aegepty betina. Upaya pencegahan DBD yang dapat kita lakukan adalah membersihkan genangan air di sekitar rumah agar terbebas dari nyamuk Aedes aegepty, menutup tempattempat penyimpanan air, menguras bak mandi minimal satu minggu sekali, membersihkan pekarangan rumah dari barang-barang bekas yang berpotensi sebagai tempat perkembangan jentik nyamuk.

\subsubsection{COVID-19}

Penyakit ini disebabkan oleh koronavirus jenis baru yang diberi nama SARS-CoV-2.Wabah COVID-19 pertama kali dideteksi di Kota Wuhan, Provinsi Hubei, Tiongkok pada bulan Desember 2019. diduga menyebar di antara orangorang terutama melalui percikan pernapasan (droplet) yang dihasilkan selama batuk. Percikan ini juga dapat dihasilkan dari bersin dan pernapasan normal. Selain itu, virus dapat menyebar akibat menyentuh permukaan benda yang terkontaminasi dan kemudian menyentuh wajah seseorang.

Penyakit COVID-19 paling menular saat orang yang menderitanya memiliki gejala, meskipun penyebaran mungkin saja terjadi sebelum gejala muncul. Periode waktu antara paparan virus dan munculnya gejala biasanya sekitar lima hari, tetapi dapat berkisar dari dua hingga empat belas hari. Gejala umum di antaranya demam, batuk, dan sesak napas. Komplikasi dapat berupa pneumonia dan penyakit pernapasan akut berat.

Untuk saat ini, tidak ada vaksin atau pengobatan antivirus khusus untuk penyakit ini. Pengobatan primer yang diberikan berupa terapi simtomatik dan suportif. Langkah-langkah pencegahan yang direkomendasikan di antaranya mencuci tangan, menutup mulut saat batuk, menjaga jarak dari orang lain, serta pemantauan dan isolasi diri untuk orang yang mencurigai bahwa mereka terinfeksi.

\subsection{MUNCULNYA COVID-19}

Pandemi coronavirus 2019-2020 atau dikenal sebagai pandemi COVID-19 adalah peristiwa menyebarnya penyakit coronavirus 2019 atau COVID-19 di seluruh dunia. Penyakit ini disebabkan oleh coronavirus jenis baru yang diberi nama SARS-CoV-2.Wabah COVID-19 pertama kali dideteksi di Kota Wuhan, Provinsi Hubei, Tiongkok pada bulan Desember 2019. 
Pasien nol yang diduga merupakan dalang pandemi ini adalah seorang wanita penjual udang di Pasar Grosir Makanan Laut Huanan, Wuhan berumur 57 tahun bernama Wei Guixiang. Awalnya, pada 10 Desember 2019, dia merasa demam dan tidak enak badan. Dia memeriksakan diri ke klinik terdekat. Namun, setelah memeriksakan diri, dia kembali berjualan. Saat itulah, SARS-CoV-2 menyebar. Setelah itu, beberapa orang mengalami gejala yang sama dan pada tanggal 31 Desember 2019, ada pemberitahuan mendesak di Wuhan tentang pneumonia yang tidak diketahui penyebabnya telah menyebar ke 25 orang.

\subsection{PENYEBARAN COVID-19 KE PENJURU DUNIA}

Virus ini menular dengan sangat cepat dan telah menyebar ke hampir semua negara, termasuk Indonesia, hanya dalam waktu beberapa bulan. Virus ini juga diduga menyebar di antara orang-orang terutama melalui percikan pernapasan (droplet) yang dihasilkan selama batuk. Percikan ini juga dapat dihasilkan dari bersin dan pernapasan normal. Selain itu, virus dapat menyebar akibat menyentuh permukaan benda yang terkontaminasi dan kemudian menyentuh wajah seseorang. Penyakit COVID-19 paling menular saat orang yang menderitanya memiliki gejala, meskipun penyebaran mungkin saja terjadi sebelum gejala muncul. Periode waktu antara paparan virus dan munculnya gejala biasanya sekitar lima hari, tetapi dapat berkisar dari dua hingga empat belas hari. Gejala umum di antaranya demam, batuk, dan sesak napas. Komplikasi dapat berupa pneumonia dan penyakit pernapasan akut berat.

Total kasus positif corona (Covid-19) di dunia semakin mendekati angka 4 juta pasien. Lonjakan jumlah kasus terus terjadi karena pada saat angka infeksi baru di sebagian negara menurun, di wilayah lain justru mengalami peningkatan pesat. Data Worldometers yang diperbarui per pukul 15.23 WIB, Rabu sore, 6 Mei 2020 menunjukkan total jumlah kasus positif corona di dunia hari ini sudah mencapai 3.741.276 pasien. Di antara 3,74 juta kasus positif corona di 212 negara dan sejumlah kawasan lain serta dua kapal pesiar itu, 258.511 pasien Covid-19 telah meninggal dunia. Sementara pasien Covid-19 yang telah sembuh baru sekitar 1.247.417 orang. Berdasarkan data update dari Wolrdometers, sebanyak 2.235.348 pasien Covid-19 di seluruh dunia saat ini masih berstatus dalam perawatan. Dari 2,23 juta orang tersebut, 49.243 ( 2 persen) pasien Covid-19 mengalami kondisi kritis atau gangguan serius.

Untuk saat ini, tidak ada vaksin atau pengobatan antivirus khusus untuk penyakit ini. Pengobatan primer yang diberikan berupa terapi simtomatik dan suportif. Langkah-langkah pencegahan yang direkomendasikan di antaranya mencuci tangan, menutup mulut saat batuk, 
menjaga jarak dari orang lain, serta pemantauan dan isolasi diri untuk orang yang mencurigai bahwa mereka terinfeksi.

Upaya yang dapat dilakukan untuk mencegah penyebaran virus termasuk pembatasan perjalanan, karantina, pemberlakuan jam malam, penundaan dan pembatalan acara, serta penutupan fasilitas. Upaya ini termasuk karantina Hubei, karantina nasional di Italia dan di tempat lain di Eropa, serta pemberlakuan jam malam di Tiongkok dan Korea Selatan, berbagai penutupan perbatasan negara atau pembatasan penumpang yang masuk, penapisan di bandara dan stasiun kereta,serta informasi perjalanan mengenai daerah dengan transmisi lokal. Sekolah dan universitas telah ditutup baik secara nasional atau lokal di lebih dari 124 negara dan memengaruhi lebih dari 1,2 miliar siswa.

Pandemi ini juga menyebabkan gangguan sosioekonomi global, penundaan atau pembatalan acara olahraga dan budaya,dan kekhawatiran luas tentang kekurangan persediaan barang yang mendorong pembelian panik. Misinformasi dan teori konspirasi tentang virus telah menyebar secara daring, dan telah terjadi insiden xenophobia dan rasisme terhadap orang Tiongkok dan orang-orang Asia Timur atau Asia Tenggara lainnya.

\subsection{PENYEBARAN COVID-19 DI INDONESIA}

Pada tanggal 14 Februari 2020, pasien terinfeksi virus corona berdansa dengan WNA Jepang. Pasien berusia 31 tahun ini memang bekerja sebagai guru dansa dan WNA asal Jepang ini juga merupakan teman dekatnya. Selang dua hari, yakni 16 Februari 2020 pasien terkena sakit batuk. Pasien kemudian melakukan pemeriksaan di rumah sakit terdekat. Namun, saat itu pasien langsung dibolehkan untuk kembali ke rumah atau rawat jalan. Sayang, sakit yang dideritanya tidak kunjung sembuh. Hingga pada 26 Februari 2020, pasien dirujuk lagi ke rumah sakit dan diminta untuk menjalani rawat inap. Pada saat itulah, batuk yang diderita pasien mulai disertai sesak napas.

Pada 28 Februari 2020, pasien mendapatkan telepon dari temannya yang di Malaysia. Dalam sambungan telepon tersebut, pasien mendapatkan informasi jika WNA Jepang yang merupakan temannya itu positif terinfeksi virus corona. Setelah menjalankan tahapan pemeriksaan di rumah sakit lama, pasien kemudian dikonfirmasi positif terinfeksi virus corona. Kemudian, pasien langsung dipindahkan ke Rumah Sakit Penyakit Infeksi (RSPI) Sulianti Saroso, Jakarta Utara. Sejumlah prosedur telah dilakukan pemerintah terkait penemuan kasus 
corona di Indonesia. Mulai dari mengisolasi rumah pasien, menjaga rumahnya hingga merawat pasien.

Sejak kasus pertama diumumkan, angka kasus positif COVID-19 terus mengalami lonjakan. Hingga 6 Mei, telah terkonfirmasi 12.438 kasus positif COVID-19 dengan 9.226 kasus aktif, 2.327 kasus sembuh, dan 895 kasus meninggal. Sebagai tanggapan terhadap pandemi ini, beberapa wilayah telah memberlakukan pembatasan sosial berskala besar (PSBB).

Sama seperti sebelumnya, langkah-langkah pencegahan yang direkomendasikan di antaranya mencuci tangan, menutup mulut saat batuk, menjaga jarak dari orang lain, serta pemantauan dan isolasi diri untuk orang yang mencurigai bahwa mereka terinfeksi. 


\section{BAB III}

\section{PENUTUP}

\subsubsection{KESIMPULAN}

Penyakit menular menurut para ahli adalah sebuah penyakit yang dapat berpindah dari satu orang ke orang lain. Hal tersebut disebut dengan penularan yang bisa terjadi secara langsung atau tidak langsung dan juga bisa menular melalui perantara atau penghubung. Beberapa jenis penyakit menular yang umum diderita oleh warga Indonesia adalah Diare, Tifus, Cacar Air, Penyakit Menular Seksual (PMS), Tuberkulosis (TB), Influenza, Campak, Pneumonia, Acquired Immunodeficiency Syndrome (AIDS), Demam Berdarah Dengue (DBD), dan penyakit yang disebabkan oleh virus yang sedang marak di penjuru dunia yaitu COVID-19.

Wabah COVID-19 pertama kali dideteksi di Kota Wuhan, Provinsi Hubei, Tiongkok pada bulan Desember 2019. Virus ini menular dengan sangat cepat dan telah menyebar ke hampir semua negara, termasuk Indonesia, hanya dalam waktu beberapa bulan. Virus ini juga diduga menyebar di antara orang-orang terutama melalui percikan pernapasan (droplet) yang dihasilkan selama batuk. Upaya yang dapat dilakukan untuk mencegah penyebaran virus termasuk pembatasan perjalanan, karantina, pemberlakuan jam malam, penundaan dan pembatalan acara, serta penutupan fasilitas.

Di Indonesia, sejak kasus pertama diumumkan, angka kasus positif COVID-19 terus mengalami lonjakan. Dan langkah-langkah pencegahan yang direkomendasikan di antaranya mencuci tangan, menutup mulut saat batuk, menjaga jarak dari orang lain, serta pemantauan dan isolasi diri untuk orang yang mencurigai bahwa mereka terinfeksi.

\subsection{SARAN}

Demikian Makalah yang saya buat, semoga Makalah ini dapat bermanfaat bagi pembaca. Karena keterbatasan pengetahuan dan referensi, Saya menyadari bahwa penulisan ini jauh dari sempurna. Apabila ada saran dan kritik yang ingin disampaikan, silahkan disampaikan kepada Saya sebab saran dan kritik yang disampaikan dapat membantu agar Makalah ini dapat disusun menjadi Makalah yang lebih baik lagi di masa yang akan datang. 


\section{DAFTAR PUSTAKA}

“Apa itu Penyakit Menular?”. Kompas.com. 4 Mei 2020. Dapat diakses melalui : https://www.kompas.com/skola/read/2020/03/02/143000069/apa-itu-penyakitmenular-?page $=$ all,

"Penyakit Menular". Jagad.id. 4 Mei 2020. Dapat diakses melalui : https://jagad.id/penyakit-menular/.

"Macam-Macam Penyakit Menular dan Cara Pencegahannya Sedini Mungkin". Liputan6.com. 4 Mei 2020. Dapat diakses melalui : liputan6.com/health/read/3922482/macam-macam-penyakit-menular-dan-carapencegahannya-sedini-mungkin.

“30 Jenis Penyakit Menular, Penyebab dan Pencegahannya”. jpkmsuryasumirat.com. 5 Mei 2020. Dapat diakses melalui https://www.jpkmsuryasumirat.com/index.php/berita/artikel/107-30-jenis-penyakitmenular-penyebab-dan-pencegahannya.

“Pandemi koronavirus 2019-2020". id.wikipedia.org. 6 Mei 2020. Dapat diakses melalui: https://id.wikipedia.org/wiki/Pandemi_koronavirus_2019\%E2\%80\%932020.

"Virus Corona (COVID-19)".alodokter.com. 6 Mei 2020. Dapat diakses melalui : https://www.alodokter.com/virus-corona.

“Update Corona 6 Mei 2020 Indonesia \& Dunia: Data Covid-19 Hari Ini”. Tirto.id. 6 Mei 2020. Dapat diakses melalui : https://tirto.id/update-corona-6-mei-2020- indonesiadunia-data-covid-19-hari-ini-flwx. 